\title{
SOME CONSUMER CHARACTERISTICS OF THE FERMENTED DAIRY PRODUCTS
}

\author{
N. Omelchenko, V. Kucheryava, M. Rogozynskyi, O. Nechyporenko \\ Chernivtsi faculty of NationalTechnicalUniversity "Kharkiv Polytechnic Institute"
}

\begin{tabular}{l}
$\quad$ Key words: \\
Fermented milk product \\
Kefir \\
Ferment \\
Bacterial composition \\
Characteristics \\
\hline
\end{tabular}

Article history:

Received 07.09.2018

Received in revised form

20.09.2018

Accepted 16.10.2018

Corresponding author:

N. Omelchenko

E-mail:

npnuht@ukr.net

\begin{abstract}
A rational and well-balanced nutrition is an important factor in maintenance of the normal functioning of human organism, increasing its antimicrobial resistance and overall stability in the unfavorable environmental conditions. There are many easy-to-digest compounds in the fermented milk products and this fact ensures their value as a traditional component in the everyday ration of Ukrainians.

Our everyday schedule is quite busy and it makes us thinking of the healthy nutrition. Kefir, sour cream, fermented baked milk and curdled milk - these healthy products are well-known to us since the childhood. Moreover, many TV advertisements are used to reminding us about 'the live lactic bacteria' hurrying to help an organism tired after unhealthy way of nutrition.

There are many dairy production factories, which manufacture various fermented milk goods. Even though the technology of their production is comparatively difficult, the technologists keep developing new and new solutions for production of new kinds of the goods. Any fermented milk product starts from the ferment that can be obtained after adding some strains of the lactic bacteria to milk. It is important to understand which kinds of the ferment can be more appropriate in each region of production, for instance, in Bucovina.

The results of analysis of the ferments used in manufacturing of kefir are reported in the paper. The bacterial composition has been analyzed and it was found that the main bacterial strains were Lactococcus lactis, Lactococcus cremoris, Lactococcus diacetilactis, Leuconostoc, Lactobacillus, Streptococcus thermophilus and some yields unable to take part in lactose souring (Saccharomyces unisporus, Saccharomyces cerevisiae). Finally the acetic acid bacteria Acetobacter aceti have also been identified in the experimental material. An organoleptic investigation of the consumer values of the examples has been carried out and the overall quality estimation was performed. It was found that a ratio between main microorganisms present in the ferments is dynamic. It is possible to govern the product's organoleptic qualities through changes in the ratio. It was proven that the kefir ferment by "Iprovit" fits the best with the local milk sources of Bucovina.
\end{abstract}

DOI: $10.24263 / 2225-2924-2018-24-5-22$ 


\title{
СПОЖИВЧІ ВЛАСТИВОСТІ ФЕРМЕНТОВАНИХ МОЛОЧнИХ ПРОДУКТІВ
}

\author{
Н.М. Омельченко, В.А. Кучерява, М.С. Рогозинський, О.В. Нечипоренко \\ Чернівецький факультет Національного технічного університету «Харківський \\ політехнічний інститут»
}

Раціональне та збалансоване харчування населення відіграє важливу роль y забезпеченні оптимальної діяльності організму споживача, формуванні його стійкості до дії інфекиій, екологічно несприятливих чинників тощо. Традииійною стравою у харчуванні украйнців є кисломолочні продукти, у яких основні поживні речовини наявні в легкозасвоюваній формі.

Ритм сучасного життя змушує нас обирати здорове харчування. Кефір, сметана, ряжанка, кисле молоко - усім з дитинства відомо про користь цих продуктів. До того ж телевізійна реклама щуодя нам нагадує про «живі бактерії», ще поспішають на допомогу стомленому безладним харчуванням організму.

В Украӥні прачює чимало підприємств з виробництва кисломолочної продукиії. Хоча прочес виробництва кисломолочних продуктів досить складний, технологи не перестають розробляти схеми для випуску нових видів такоі продукиії. Основою будь-якого кисломолочного продукту є закваска, що виходить при додаванні в різні види молока визначених молочнокислих бактерій, так званих штамів. Для того, щоб отримати якісний продукт, важливо визначити, які саме типи заквасок підходять для конкретного регіону, у нашому випадку для Буковини.

У статті проведено аналіз асортименту заквасок, що використовуються для виготовлення кефірів. Проаналізовано їх бактеріальний склад, щзо переважно представлений молочнокислими бактеріями Lactococcus lactis, Lactococcus cremoris, Lactococcus diacetilactis, Leuconostoc, Lactobacillus, Streptococcus thermophilus, дріжджами, нездатними до зброджування лактози Saccharomyces unisporus, Saccharomyces cerevisiae та оцтовокислими бактеріями Acetobacter aceti. Здійснено органолептичну оцінку споживчих властивостей та аналіз якості отриманих кефірів. Встановлено, що співвідношення між основними групами мікроорганізмів досліджуваних кефірних заквасок є динамічним, коригуючи його, можна впливати на органолептичні характеристики кіниевого продукту. Експериментально визначено, щзо кефірна закваска TM «Іпровіт» оптимально адаптована до молочної сировини сировинної зони Буковини.

Ключові слова: кисломолочний продукт, кефір, закваска, бактеріальний склад, властивості.

Постановка проблеми. Проблема забезпечення населення України збалансованим харчуванням в умовах сьогодення набуває особливої актуальності. У рамках національної стратегії збереження здоров'я нації сьогодні в Україні відбувається переосмислення культури споживання їжі. Нині органі- 
зація харчування грунтується на принципах концепції збалансованого харчування, розробленій акад. А.А. Покровським, та на положеннях теорії адекватного харчування, сформульованій акад. А.М. Уголєвим. Остання зосереджена на функції вторинних метаболітів в організмі і передбачає, що харчування має бути не тільки збалансованим, але й відповідати можливостям організму і природним механізмам засвоєння їжі.

Зважаючи на сучасні екологічні умови, раціон харчування людини повинен містити в собі природні біологічно активні речовини, які здатні підвищувати резистентність організму [1].

Молочна промисловість — одна 3 провідних галузей агропромислового комплексу України: питома вага молочної галузі в загальному обсязі харчової та переробної промисловості складає 11\% [2]. Молочні продукти становлять обов'язкову складову раціону харчування кожної людини, тому увага до виробництва молочної продукції є значною.

Для молочної промисловості відкрилися нові можливості для розробки i впровадження продуктів підвищеної харчової й біологічної цінності. Ці можливості успішно реалізуються провідними вченими і виробниками завдяки біотехнологічним прийомам.

Аналіз останніх досліджень і публікацій. Проблеми розвитку біотехнології кисломолочних (ферментованих молочних) продуктів спеціального призначення досліджували такі українські та зарубіжні вчені: Н.Ф. Кігель, Т.А. Скорченко, Ю.Р. Гачак, Н.Б. Сливка, І.М. Турчин, Г.Є. Поліщук, І.О. Романчук, Н.Б. Гаврилова, Л.А. Забодалова, В.Ф. Сємєніхіна, В.И. Ганіна, А.Г. Храмцов, Б.А. Шендеров, A.Y. Tamime, R.K. Robinson, M.E. Sharpe, R.M. Fry та інші.

Найбільш активні розробки ведуться в напрямку інтенсифікації та удосконалення технологічних процесів виробництва молочних продуктів, а також збільшення харчової та біологічної цінності молочних продуктів, їх стійкість при зберіганні, створення нових видів продуктів, зокрема для дієтичного та дитячого харчування, замінників цільного молока для потреб тваринництва, більш повного та ефективного використання вторинної сировини (знежиреного молока, сироватки та сколотини).

Асортимент кисломолочних продуктів на вітчизняному ринку досить різноманітний, проте серед них часто переважають ті, що мають синтетичні, ненатуральні або умовно-натуральні зі зміненим хімічним складом і властивостями речовини. Штучні наповнювачі, стабілізатори, згущувачі, модифіковані молочні компоненти вторинної переробки знижують цінність натуральних кисломолочних продуктів. Тому особливо актуальним $\epsilon$ створення синбіотичних кисломолочних продуктів, які б мали високі споживчі властивості та якість завдяки застосуванню суто натуральних компонентів [3]. Цього можна досягнути шляхом правильного підбору стартерних культур, які входять до складу закваски.

Кисломолочні продукти мають значну цінність 3 погляду фізіології харчування. Під дією молочної кислоти казеїн молока коагулює у вигляді дрібних пластівців, і засвоюваність кисломолочних продуктів покращується. У кислому молоці та кефірі міститься значна кількість жиророзчинних вітамінів A, D, Е, що накопичуються в результаті життєдіяльності бактерій. Сир і 
кисломолочні напої багаті на солі фосфору, кальцію, магнію, які беруть участь в обміні речовин організму людини. Кумис, кефір, ацидофільно-дріжджове молоко містять діоксид вуглецю і молочну кислоту, залишки алкоголю, що справляють потужний секреторний вплив на травні залози, поліпшуючи таким чином процес травлення і засвоєння їжі. Кисломолочні продукти містять у достатній кількості незамінні амінокислоти, які легко засвоюються [3].

Кефір - традиційний продукт молочнокислого та спиртового бродіння [4; 5]. У той же час - це єдиний кисломолочний напій, який виробляють на природній симбіотичній заквасці - кефірних грибках $[3 ; 6 ; 8]$.

Сквашування молока молочнокислими бактеріями й дріжджами широко використовується в Східній Європі, у т. ч. й в Україні, для виробництва кефіру й кумису. При цьому типі бродіння в продукті утворюється молочна кислота, спирт, двоокис вуглецю й ароматичний смакові речовини [3; 6]. Завдяки цьому кефір володіє всіма корисними властивостями кисломолочних напоїв і належить до дієтичних продуктів. Його унікальність зумовлена застосуванням кефірних грибків - живого природного симбіозу багатьох видів бактерій і дріжджів. У природну симбіотичну закваску для кефіру (кефірні грибки) входять лактококи (гомоферментативні мезофільні L. lactis i L. cremoris, гетероферментативні мезофільні L. diacetilactis, представники роду Leuconostoc, термофільний стрептокок S. thermophilus), лактобактерії (гомоферментативні L.helveticus, L. acidophilus, L. bulgaricus; гетероферментативні L. plantarum L. rhamnosus (casei)), дріжджі й оцтовокислі бактерії [5; 7].

Отриманні шляхом змішаного бродіння кисломолочні продукти збагачені незначною кількістю спирту і вуглекислоти, а тому покращують роботу дихального та судинного центрів, злегка збуджують центральну нервову систему [8]. Систематичне вживання кисломолочних напоїв покращує здоров'я людини, підвищує стійкість до інфекцій і утворення пухлин, рекомендуються хворим, які мають харчову алергію, захворювання шлунково-кишкового тракту.

Ферментованими є харчові продукти, для виготовлення яких використовують мікроорганізми із високою біологічною активністю. У процесі життедіяльності мікрофлора заквасок зброджує вуглеводи вихідної сировини, утворюючи різні продукти метаболізму - органічні кислоти, вітаміни, амінокислоти, ефіри, антибіотичні речовини тощо. Тож у процесі ферментації зменшується калорійність продукту, зростає засвоюваність поживних речовин та підвищується біологічна цінність [6;9].

Мета дослідження: проаналізувати різні види заквасок для виготовлення кефіру термостатним способом та визначити оптимально адаптовану закваску до молочної сировини сировинної зони Буковини.

Матеріали і методи. Якісну оцінку кисломолочних продуктів, одержаних із використанням досліджуваних бактеріальних заквасок, проводили згідно із загальноприйнятими методиками та нормативними документами: ДСТУ ISO 707-2002 «Молоко і молочні продукти»; настанови з відбирання проб ДСТУ ISO 5538:2004 «Молоко і молочні продукти. Відбирання проб. Контроль за якісними показниками». Органолептичні показники кефіру (зовнішній вигляд, консистенцію, колір, визначали візуально, смак і запах) визначали органолептично. Активну кислотність визначали за ГОСТ 26781-85, титровану — за 
ГОСТ 3624-92. Якісний бактеріальний склад мікрофлори кефірних заквасок визначали за ГОСТ 10444.11-89.

Результати і обговорення. Предметом дослідження були сухі бактеріальні закваски: «VIVO кефір» (розробки Державного підприємства бактеріальних заквасок технологічного інституту молока та м'яса «Альба-ТІММ»); «Keфip TM «Good Food» (італійського центру з дослідження та розвитку біохімії BIOCHEM srl.), «Кефір» ТМ «Ппровіт» (виробництва Державного дослідного підприємства Інституту продовольчих ресурсів НААН України). Бактеріальний склад заквасок наведено у табл. 1.

Таблиця 1. Бактеріальний склад досліджуваних заквасок

\begin{tabular}{|c|c|c|}
\hline $\begin{array}{l}\text { № } \\
\text { 3/П }\end{array}$ & Найменування закваски & Склад закваски \\
\hline 1 & Vivo кефip (Україна) & $\begin{array}{l}\text { Lactococcus lactis subsp. lactis; Lactococcus lactis subsp. } \\
\text { diacetylactis; Lactobacillus acidophilus; Lactobacillus } \\
\text { delbrueckii subsp. bulgaricus; Lactobacillus casei; } \\
\text { Acetobacter aceti; Streptococcus salivarius subsp. } \\
\text { thermophilus; Saccharomyces unisporus }\end{array}$ \\
\hline 2 & $\begin{array}{c}\text { Кефip ТМ «Іпровіт» } \\
\text { (Україна) }\end{array}$ & $\begin{array}{c}\text { Мікрофлора кефірних грибків, Lactococcus lactis } \\
\text { subsp.lactis, Streptococcus salivarius subsp. thermophilus, } \\
\text { Saccaromices unisporus }\end{array}$ \\
\hline 3 & $\begin{array}{c}\text { Keфip } \\
\text { TM Good Food (Італія) }\end{array}$ & $\begin{array}{l}\text { Leuconostoc mesenteroides subsp. cremoris; Lactococcus } \\
\text { lactis subsp. cremoris; Lactobacillus lactis subsp. lactis; } \\
\text { Lactococcus lactis subsp. lactis biovar. diacetylactis; } \\
\text { Lactobacillus acidophilus; Lactobacillus delbrueckii } \\
\text { subsp. bulgaricus; Saccharomyces cerevisiae }\end{array}$ \\
\hline
\end{tabular}

Завдяки такій широкій багатовидовій мікрофлорі в процесі сквашування кефіру відбувається накопичення широкої гами смакових і ароматичних речовин, які надають готовому продукту чистого кисломолочного запаху i специфічного освіжаючого смаку з «щипким» присмаком.

На першому етапі експерименту досліджували час та якість ферментації молока при використанні сухих заквасок. Як вихідну сировину використовували пастеризоване молоко з масовою часткою жиру 2,5\%. Ферментацію заквашених зразків проводили термостатним способом у скляній тарі при температурі $(37 \pm 1)^{\circ} \mathrm{C}$. Період сквашування молочної сировини при одержанні зразків кефірів відповідно до рекомендацій виробників тривав від 6 до 8 год: за використання закваски TM «провіт» - 6 год, закваски «Vivo кефір» 7,5 год, TM Good Food - 8 год.

Протягом зазначеного часу ферментації в усіх досліджуваних зразках досягається ізоелектричний стан білків під впливом суміші молочної та оцтової кислот, активна кислотність досліджуваних зразків складає 4,52-4,75 pH. Визначення титрованої кислотності після закінчення періоду ферментації показало, що кефір, отриманий із використанням закваски ТМ «Іпровіт», має найнижче значення $90^{\circ} \mathrm{T}$, а при використанні закваски TM Good Food готовий продукт має найбільше значення титрованої кислотності $110^{\circ} \mathrm{T}$. Загалом, титрована кислотність досліджуваних зразків коливається в межах 90$110^{\circ} \mathrm{T}$, що відповідає вимогам НТД [10]. 
На другому етапі визначали органолептичні властивості отриманих кисломолочних продуктів. Увагу зосереджено, зокрема, на органолептичних показниках для визначення кращої закваски для виготовлення кефіру. Для цього було розроблено шкалу оцінки якості готового продукту. Органолептичні показники якості досліджуваних зразків визначалися за бальною шкалою (табл. 2).

Таблиця 2. Бальна шкала оцінки органолептичних показників продуктів

\begin{tabular}{|c|c|c|}
\hline Показник & Бал & $\begin{array}{c}\text { Коефіцієнт } \\
\text { вагомості }\end{array}$ \\
\hline Смак & $\begin{array}{c}5 \text { - смак щипкий, без сторонніх присмаків і запахів; } \\
4 \text { - слабкий кисломолочний із легким присмаком; } \\
3 \text { - слабкий кисломолочний із солодкуватим присмаком; } \\
2 \text { - чистий кисломолочний; } \\
1 \text { - кисломолочний із сильним присмаком }\end{array}$ & 0,28 \\
\hline Запах & $\begin{array}{c}5-\text { чистий, кисломолочний; } \\
4-\text { характерний кисломолочний із легким ароматом; } \\
3-\text { характерний кисломолочний; } \\
2-\text { насичений аромат; } \\
1 \text { - кисломолочний із нехарактерним ароматом }\end{array}$ & 0,24 \\
\hline Консистенція & $\mid \begin{array}{c}5 \text { - однорідна, в'язка, з непорушеним згустком; } \\
4-\text { однорідна з ледве помітними включеннями; } \\
3 \text { - неоднорідна з включеннями; } \\
2 \text { - неоднорідна з помітними включеннями; } \\
1 \text { - неоднорідна з помітними включеннями, розшарування } \\
\text { кисломолочної основи }\end{array}$ & 0,25 \\
\hline Колір & \begin{tabular}{|c|}
5 - молочно-білий, рівномірний за всією масою; \\
4 - однорідний білий або білий з легким відтінком; \\
3 - неоднорідний білий з відтінком; \\
2 - білий із нехарактерним відтінком; \\
1 - неоднорідний білий із нехарактерним відтінком
\end{tabular} & 0,23 \\
\hline
\end{tabular}

Оцінку якості отриманих кефірів було проведено експертним методом, який грунтується на основних думках експертів. До складу експертної комісії входили 50 споживачів, які належали до різних соціальних груп і вікових категорій. Їм було запропоновано три види кефіру, виготовлених термостатним способом із використанням заквасок TM «Vivo», TM «Іпровіт» і TM «Good food».

Експертна комісія обрала стандартні показники якості: смак і запах, консистенцію, колір. У табл. 3 наведено ранжування за обраними показниками якості кефіру.

Таблиия 3. Ранжування експертною комісісю органолептичних показників якості дослідних зразків продукту

\begin{tabular}{|c|c|c|}
\hline Показник & Сума рангів & Коефіціснт вагомості \\
\hline Смак & 4,2 & 0,28 \\
\hline Запах & 3,7 & 0,24 \\
\hline Консистенція & 3,8 & 0,25 \\
\hline Колір & 3,3 & 0,23 \\
\hline Сума & 15 & 1 \\
\hline
\end{tabular}


Експертами оцінено органолептичні показники якості кефірів, отриманих із використанням досліджуваних заквашувальних культур. У табл. 4 наведено порівняльну характеристику органолептичних властивостей трьох видів кефіру.

Таблиця 4. Результати оцінки якості кефіру за органолептичними показниками

\begin{tabular}{|c|c|c|c|c|c|}
\hline \multirow{2}{*}{ Продукт } & \multicolumn{4}{|c|}{ Показник якості з урахуванням коефіцієнтів } & \begin{tabular}{c} 
Загальна \\
оцінка \\
\cline { 2 - 5 }
\end{tabular} \\
\cline { 2 - 5 } & $\begin{array}{c}\text { Смакомості } \\
(0,28)\end{array}$ & $\begin{array}{c}\text { Запах } \\
(0,24)\end{array}$ & $\begin{array}{c}\text { Консистенція } \\
(0,25)\end{array}$ & $\begin{array}{c}\text { Колір } \\
(0,23)\end{array}$ & $\begin{array}{c}\text { продукту в } \\
\text { балах }\end{array}$ \\
\hline Закваска Vivo & 4,0 & 3,8 & 3,4 & 3,3 & 14,5 \\
\hline Закваска Iпровіт & 4,5 & 4,1 & 4,2 & 3,5 & 16,3 \\
\hline Закваска Good food & 4,1 & 4,0 & 4,0 & 3,1 & 15,2 \\
\hline
\end{tabular}

Дегустаційна комісія відзначила високі органолептичні властивості всіх досліджуваних зразків. Особливо позитивними відтінками смаку і запаху відрізнявся кефір, виготовлений із кефірної закваски ТМ «Іпровіт».

Виробництво кефіру регулюється міжнародними та державними нормативними документами. Цей напій відповідно до Закону України «Про молоко та молочні продукти» визнається кефіром лише тоді, коли він виготовляється зі застосуванням кефірних грибків чи кефірної грибкової закваски [11]. До нормальної мікрофлори кефірної закваски належать такі основні групи бактерій: гомо- і гетероферментативні молочнокислі коки родів Lactococcus, Leuconostoc, молочнокислі палички роду Lactobacterium, дріжджі та оцтовокислі бактерії Acetobacter aceti [7].

Також досліджено якісний склад мікрофлори грибкових кефірних заквасок. Встановлено, що мікрофлора заквасок представлена молочнокислими бактеріями Lactococcus lactis, Lactococcus cremoris, Lactococcus diacetilactis, Leuconostoc, Lactobacillus, Streptococcus thermophilus, дріжджами, нездатними до зброджування лактози Saccharomyces unisporus, Saccharomyces cerevisiae та оцтовокислими бактеріями Acetobacter aceti. Співвідношення між групами бактерій $є$ динамічним. Мікробіота кефірної закваски ТМ «Іпровіт» є найбільш придатною для сквашування молочної сировини сировинної зони Буковини.

\section{Висновки}

Кефірна закваска ТМ «Іпровіт» оптимально адаптована до молочної сировини досліджуваної сировинної зони.

Співвідношення між основними групами мікроорганізмів кефірних заквасок $€$ динамічним, коригуючи його, можна впливати на органолептичні характеристики кінцевого продукту.

Подальший напрямок досліджень вбачається у вивченні якісного та кількісного складу фруктових добавок для одержання функціональних молочних продуктів і розширення асортименту місцевих підприємств.

\section{Література}

1. Турчин І., Гамкало Х., Войчишин А. Використання молочної сироватки при виробництві десертів. Науковий вісник ЛНУ ветеринарної медицини та біотехнологій. 2017. № 19(80). C. 165-168. URL: https://nvlvet.com.ua/index.php/journal/article/view/1392 
2. Федулова I. Ринок молочної продукції України: можливості та загрози. Товари $i$ ринок. 2018. № 1(25). C. 15-28. URL: http://tr.knteu.kiev.ua/files/2018/01(25)/04.pdf.

3. Мікробіологія молока і молочних продуктів 3 основами ветеринарно-санітарної експертизи: навч. посіб. [для підготовки фахівців у ВНЗ III-IV рівнів акредитації за напрямками підготовки «Харчові технології та інженерія» і «Ветеринарна медицина»] / Бергілевич О.М., Касянчук В.В., Салата В.З. та ін.; за ред. д. вет. н., проф. В.В. Касянчук. Суми: Університетська книга, 2010. 320 с.

4. Технологічні комплекси харчових виробництв: навч. посібник / B.I. Теличкун, О.М. Гавва, Ю.С. Теличкун, О.О. Губеня, М.Г. Десик, О.М. Чепелюк. Київ: Видавництво «Сталь», 2017. $456 \mathrm{c.}$

5. Гудима В.В., Кігель Н.Ф. Відбір дріжджів для залучення до складу заквашувальних композицій для виробництва кефіру. Продовольчі ресурси. Серія: Технічні науки. 2015. № 4. C. 87—91. URL: http://nbuv.gov.ua/UJRN/prrteh_2015_4_18.

6. Yerlikaya O. Starter cultures used in probiotic dairy product preparation and popular probiotic dairy drinks. Food Science and Technology. 2014. Vol.34, no 2. P. 221-229. URL: http://dx.doi.org/10.1590/fst.2014.0050.

7. Гудима В.В., Кігель Н.Ф. Виділення, ідентифікація та вивчення властивостей молочнокислих бактерій із кефірних грибків та кефіру. Продовольчі ресурси. 2014. № 2. C. $64-70$.

8. Гачак Ю.Р., Варивода Ю.Ю., Сливка Н.Б. Молочні продукти лікувально-профілактичного призначення. Львів, 2011. 136 с.

9. Panesar P.S. Fermented dairy product: starter cultures and potential nutritional benefits. Food and Nutrition Sciences. 2011. Vol.2, №1. P. 47-51. DOI:10.4236/fns.2011.21006.

10. ДСТУ 4417:2005. Кефір. Технічні умови. Чинний від 01.07.2006.

11. Виробництво кефіру згідно з національним стандартом України. Молокопереробка. 2006. № 5(8). С.8-11. 